$\xi=-1$

\title{
Trends Analysis of Ozone Hole Annual Records Using SBUV Data Version 8.6 (1979 to 2017 Datasets)
}

\author{
Mohd Ekhwan Toriman ${ }^{1}$, Musa Garba Abdullahi ${ }^{2,3}$, Mohd Khairul Amri Kamarudin ${ }^{2 *}$, Roslan Umar ${ }^{2}$, Aliyu Mu- \\ hammad Nalado ${ }^{2}$, Md Firoz Khan ${ }^{4}$ \\ ${ }^{1}$ Faculty of Social Sciences and Humanities, Universiti Kebangsaan Malaysia, 43600, Bangi, Selangor, Malaysia \\ ${ }^{2}$ East Coast Environmental Research Institute (ESERI), Universiti Sultan Zainal Abidin Gong Badak Campus, 21300 Kuala Nerus, Ma- \\ laysia \\ ${ }^{3}$ Department of Physics, Faculty of Science, Yusuf Maitama Sule University, Kano, City CampusKofar Nasarawa, Kano-Nigeria \\ ${ }^{4}$ Centre for Tropical Climate Change System, Institute of Climate Change, Universiti Kebangsaan Malaysia, 43600 Bangi, Selangor, \\ Malaysia \\ *Corresponding author E-mail: mkhairulamri@unisza.edu.my
}

\begin{abstract}
Ozone is the triatomic of oxygen forms within the Earth's atmosphere from the ultraviolet dissociation of oxygen molecules, within tropical stratosphere. It is conveyed toward the extratropics through the Brewer-Dobson circulation (BDC), generating a layer in the stratosphere known as a protective ozone layer. The data from NASA and NOAA measurements of ozone shows that the ozone layer has stopped deteriorating across the world; nonetheless no strong intensification has been detected at latitudes amongst $60^{\circ} \mathrm{S}$ and $60^{\circ} \mathrm{N}$ in the outer the Polar Regions within $60^{\circ}$ to $90^{\circ}$.In this study, the evidence of the ozone hole from satellite measurements, and evidence that ozone within the lower stratosphere at the amid of $60^{\circ} \mathrm{S}$ and $60^{\circ} \mathrm{N}$ has continuous to decline after the Montreal Protocol. This study explained that, upper stratospheric ozone is improving; the recent descending trend in the lower stratosphere prevails, consequential in a descending trend in stratospheric ozone amongst $60^{\circ} \mathrm{S}$ and $60^{\circ} \mathrm{N}$. The trend indicated that by 2060 to 2080, the ozone hole is expecting to have complete heal. Hence, the details for the continual decrease of ozone in the lower stratosphere are not clear; this study models do not prescribe these trends, and thus is a gap for another research.
\end{abstract}

Keywords: Ozone Hole; Trend analysis; Ozone Depleting Substances; Time series; Montreal Protocol.

\section{Introduction}

The ozone layer came to existence in 1913 after discovered by Charles Fabry a French physicists and his colleague Henri Buisson. The capability of ozone layer is the absorption of harmful ultraviolet radiation coming from the sun [1]. Ozone has the ability to absorb almost $97-99 \%$ of the scattered harmful ultraviolet radiations emitted from the sun and it can produce long term overwhelming effects on human beings and to the entire plants and animals $[2,3]$. To comprehend the subject matter (ozone layer), one must know where it is situated. It would be supportive to distinguish the types of layers situated in the atmosphere. The earth's atmosphere is comprising of several layers; each layer has significant activities carried out within it. The first layer is known as troposphere, it extending roughly 10 kilometers upwards from the earth's surface. Most of the human activities such as small aircraft, mountain climbing, and gas balloons, and other related activities are taken place within this region.

The second layer is known as stratosphere which is above the troposphere prolonging approximately from 15 to 60 kilometers. It is the region of ozone layer, which is accumulated in the lower section of the stratosphere extending from 20-30 kilometers from the surface of the earth. Ozone layer has the thickness of about 3 to $5 \mathrm{~mm}$; nevertheless, it pretty much alters conditionally by the season and geography. Ozone layer is a profound layer within the earth's atmosphere contains ozone which is a naturally existing molecule consisting a three oxygen atoms $\left(\mathrm{O}_{3}\right)$. It formed a molecules gaseous layer within the Earth's stratosphere. This stratosphere is the lower region containing reasonably higher ozone concentration known as Ozonosphere. However, this Ozonosphere is originating around $15-35 \mathrm{~km}$ above the earth's surface. Ozone is a strange type of oxygen consists of 3 oxygen atoms as a substitute of the usual 2 oxygen atoms. The ozone layer typically grows once an uncommon type of radiation or electrical discharge splits the two-oxygen atom from its molecule $\mathrm{O}_{2}$, which reunite autonomously with other kind of molecules of oxygen to form ozone.

The ozone concentration within the ozone layer is commonly below 10 parts per million though the average ozone concentration within the atmosphere is around 0.3 parts per million. The ozone layer thickness differs accordingly depend on the season and geography. The maximum ozone concentrations found at the altitudes from 26 to $28 \mathrm{~km}$ within the tropics regions and from 12 to $20 \mathrm{~km}$ near the poles. The ozone layer is a thick coating layer in the stratosphere, surrounding the earth with a large quantity of ozone within it. This layer protects the life on earth by reducing the effects of strong ultraviolet (UV) radiation emitted by the sun. Because this UV radiation is harmful rays that have the risk to human for example deadly syndromes such as skin cancer, damage of the immune system and cataracts etc. it also has the capacities of destroying cells especially single cell organism, aquatic ecosystems and other terrestrial plant life [4-8]. However, studies 
from a reliable scientific approach have verified that the source of depletion of the ozone layer is due to human activity, precisely, chemicals produce by human made which comprise halogens group especially bromine, chlorine or fluorine. These chemicals are generally recognized as Ozone Depleting Substances (ODSs). In the early 1970s scientists have detected the depletion in stratospheric ozone. The depletion was more prominent in Polar Regions as detected. The ozone layer depletion has drop down effects that causes global warming, it also sequentially brings about melting of the polar ice, causes rising of the sea levels and global climatic changes [9-12].

There are natural phenomena that cause depletion in the Ozone layer for example stratospheric winds and Sunspots. Nonetheless these natural phenomena might cause a few such that it will be 1$2 \%$ depletion of the ozone layer. However, the effects are considered temporary due to the rapid recovered. Another natural cause is the volcanic eruption and such as reported in 1991, Pinatubo (Philippines) and El Chichon in 1983. Therefore, the highest source for the depletion of ozone is resolute as extreme emission of bromine and chlorine from industries, companies and residential areas such as volatile organic compounds (VOCs), Methyl chloroform $\left(\mathrm{CH}_{3} \mathrm{CCl}_{3}\right)$, chlorofluorocarbons (CFCs). CFCs (chlorofluorocarbons), Carbon tetrachloride $\left(\mathrm{CCl}_{4}\right)$, hydrochlorofluorocarbons (HCFCs), halons, hydrobromofluorocarbons and methyl bromide are considered to have direct effect on the ozone layer depletion. These chemical compounds are all characterized as ozone-depleting substances (ODSs). The delicate with the ODSs is that they continue to stay in the atmosphere for relatively a long time unwashed, and with firmness, it then transported to the lower stratosphere. The release of ODSs produced about $90 \%$ of the total ozone layer depletion within the stratosphere. These gases break out by ultraviolet radiations from the sun to release chlorine (from CFCs) and bromine (from methyl bromide and halons) when reaching the stratosphere region of the atmosphere. The free radicals of chlorine and bromine react with $\mathrm{O}_{3}$ molecule and destroy their molecular structure, consequently depleting the ozone layer. Studies entail that one atom of chlorine breakdown over 100,000 ozone molecules. And bromine atom is thought to be 40 times destructive than that cause by chlorine molecules.

\section{Material and Methods}

\subsection{The Ozone Hole}

In 1984 Joseph Farman a British Antarctic Survey scientists, and his coworkers Jonathan Shanklin and Brian Gardiner, revealed a recurrent spring Antarctic ozone hole. Their finding was available in a Journal (Nature), published May 1985. Their study concise data obtained during the British Antarctic Survey indicating that ozone levels had decreased to about $10 \%$ from the normal January points for Antarctica.

The ozone "hole" is actually seen as a decreased in concentrations of ozone within the stratosphere above the earth. The ozone hole refers to geographically as the zone where the total ozone quantity is below 220 Dobson Units. The ozone hole has gradually increases in size to about 27 million sq. $\mathrm{km}$. and its length of existence started in August to the early December since the few decades [13]. After the Montreal Protocol and series of rigorous conferences and consultations, on ODSs that deplete the Ozone Layer was lastly approved on 16 September 1987 in the Montreal held at the Headquarters of the International Civil Aviation Organization. The Montreal Protocol specifies that the manufacture and ingesting of composites that deplete the stratospheric ozone such as methyl chloroform, chlorofluorocarbons (CFCs), carbon tetrachloride and halos, are banned by 2000 and suggested only methyl chloroform to be by 2005 . Scientific evidence and theory propose that, once these compounds are emitted into the atmosphere, it could considerably deplete the ozone layer of the stratosphere. Hence, it is the layer that shields the earth from a harmful Ultraviolet-B radiation. Nonetheless, the Man-made chlorines, predominantly chlorofluorocarbons (CFCs), leads to the thinning of the ozone layer and create a greater amount of destructive ultraviolet rays to influence the earth's surface. Fig. 1 explains about the ingesting of ozone depleting substances articulated.

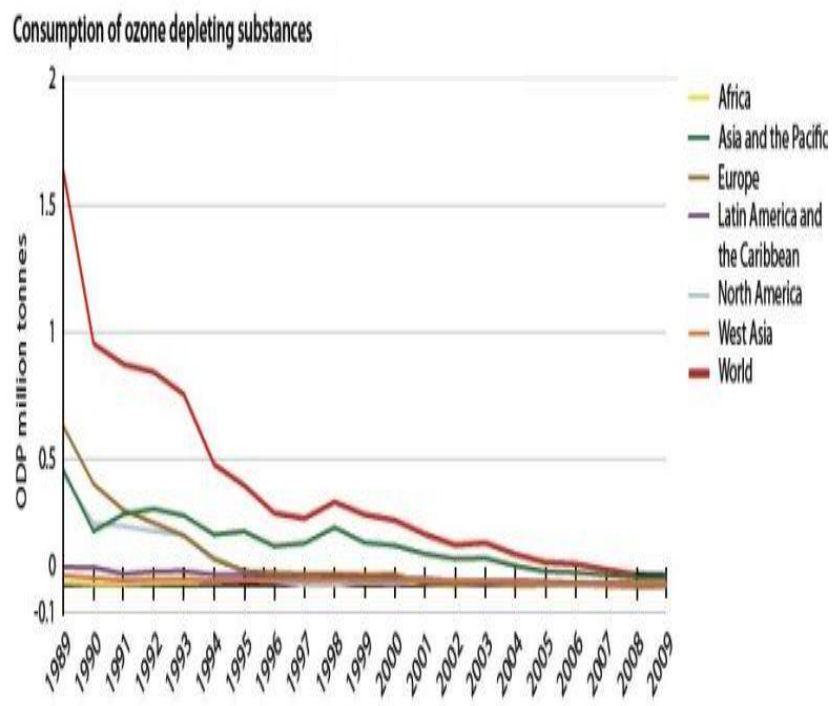

Fig. 1: The ingesting of ozone depleting substances articulated as million tons of ozone depletion potential (ODP), 1989 to 2009.

Ozone Depletion Potential is a number that define the quantity of ozone depletion caused due to the emission of chemical substance. Ingesting of ozone depleting substances has basically reduced for the last 30 years. Data source: The Montreal Protocol (UNEP 2010)

However, long-term satellite data from observatories by NASA indicated the reduction in levels of chlorine of about 20 percent within the Earth's atmosphere ever since 2005. It is an achievement for the banned of ODSs due to the first worldwide action on Montreal Protocol and noticed a dramatic impact on the earth. We understand clearly that chlorine emit from CFCs is decreases in the ozone hole, and that leads to heal of ozone from depletion. Decades later, the destruction is gradually reduced, with scientists observing that the ozone hole has contracted by 4 million square $\mathrm{km}$ complete later by the year 2000 . However, it's a great indication that the protective ozone layer within the Antarctica region is lowering to about $20 \%$ throughout the 2016 Antarctica winter then during the same time in 2005. But the size of the hole alone doesn't express the entire story. Actually, the zone of the hole varies every year, larger in size during October. Hence this seasonal shift is as a result of the CFCs which stay afloat within the atmosphere for about a century and augmented Ultraviolet radiation at certain periods within the year kick start the process of ozone depletion repeatedly [14].

In [15] clarified that; as stimulating as the result is, we are still using the woods. This study not emitting the new CFCs into the atmosphere; nevertheless, the present ones were stagnated for a while within the atmosphere. "CFCs and other ODSs have lifetimes for about 50 to 100 years, and this remains within the atmosphere for a longtime." This study also mentioned that; the ozone hole can be healing by 2060 or 2080 . And even though they might be remained with a small hole." On Sept. 11, 2017, Earth's ozone hole extended across an area nearly two and a half times the size of the United States.

\subsection{Ozone Profile Data Records}

The determination of ozone trends necessitates the uses of homogeneous data records that range for several years (decades), since not only ozone fluctuations related with the quasi-biennial oscilla- 
tion must be measured as well, nevertheless also the slow fluctuations related with the 11-year solar cycle $[16,17]$. The available long-term dataset records of ozone data profile start since before the 80 s and prolong to the present time (see also [18, 19, 20,21, 22]). This data was obtained from NASA Data based. It is the data of the maximum of the daily ozone hole size and the minimum of the Southern Hemisphere daily ozone minimums for each year and the date of occurrence.

\subsection{Trend Analysis}

In statistics, the uses of trend analysis frequently refer to techniques for mining or extracting a fundamental pattern of performance in a time series which would else be partially or nearly entirely concealed by noise [23]. If the trend can be presumed to be linear, trend analysis can be assumed within a formal regression analysis, as designated in Trend estimation. If the trends have different shapes other than linear, trend analysis can be done using non-parametric methods, such as Mann-Kendall test, which is a form of Kendall rank correlation coefficient. For testing and picturing of nonlinear trends also we can use smoothing as well.

\section{Results and Discussion}

Although all the measurements are inter-calibrated within (SBUV) the Version 8.6 processing, other problems such as the hardware, or instrument malfunction, calibration drifts, time-dependent, and altering orbital characteristics might cause an unpredictable measurement amongst instruments which must be considered before assembling the amalgamated data set. Hence, all these problems are not included since the data is in order and do not need further anomalies processing.

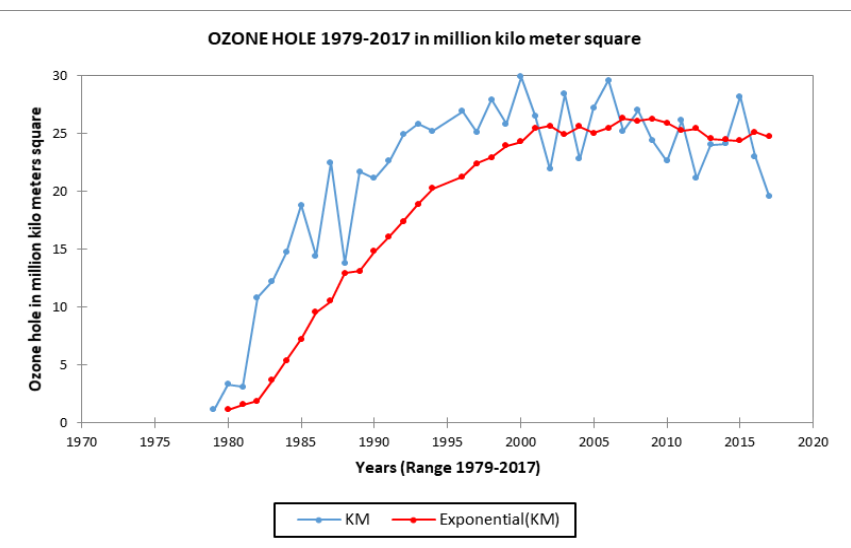

Fig. 2 (A): The graphs show the variations of ozone from year to year in unit million kilometers.

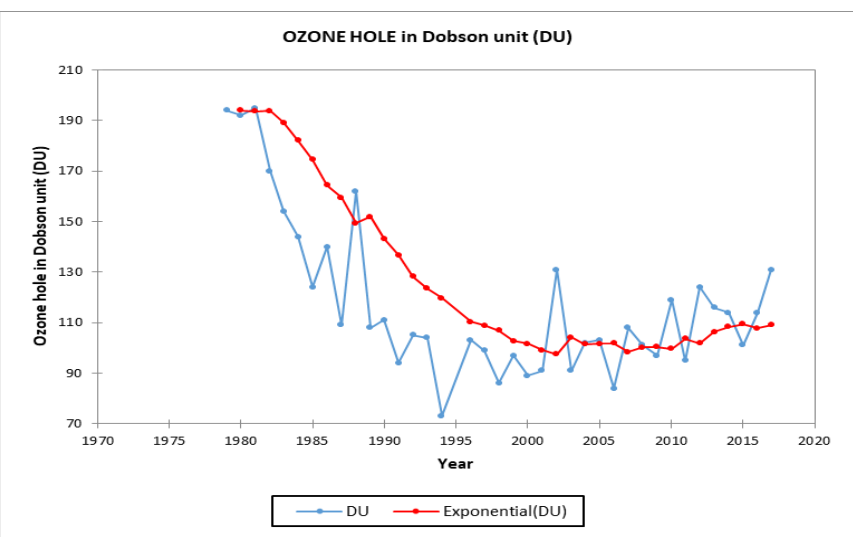

Fig. 2 (B): The graphs show the variations of ozone from year to year in Dobson unit.
We use the 1979 to 2017 period for demonstrative of the trends, in the Ozone hole to highlight the variations from the early portion of the record to date. Only measurements obtained from the National Aeronautics and Space Administration (NASA) Solar Backscattered Ultraviolet (SBUV) are shown, with each instrument showed by a different chat in Million kilometers (million $\mathrm{km}^{2}$ ) and in Dobson units (DU). We found the high degree of steadiness amongst equipment/instruments in total ozone.

By considering the chats in the Fig. 2 (A) and Fig. 2 (B) we have seen the variation of ozone decade by decade. It indicates the year 1994 with the lowest minimum value of ozone and indicates the largest area of the Ozone hole after Montreal Protocol in 1987. The year-to-year variations are superimposed on a trend encompassing over the last three decades.

The part of the ozone hole is showed from a Fig. 3 and Fig 4. (The map of total column ozone). It is evaluated from the zone on the Earth that is bounded by a contour line with a known value of 220 Dobson Units. The value of 220 Dobson Units is selected as a yardstick since the aggregate ozone values of less than 220 Dobson Units was not traces for the total historic data observed on the region of Antarctica earlier to 1979.

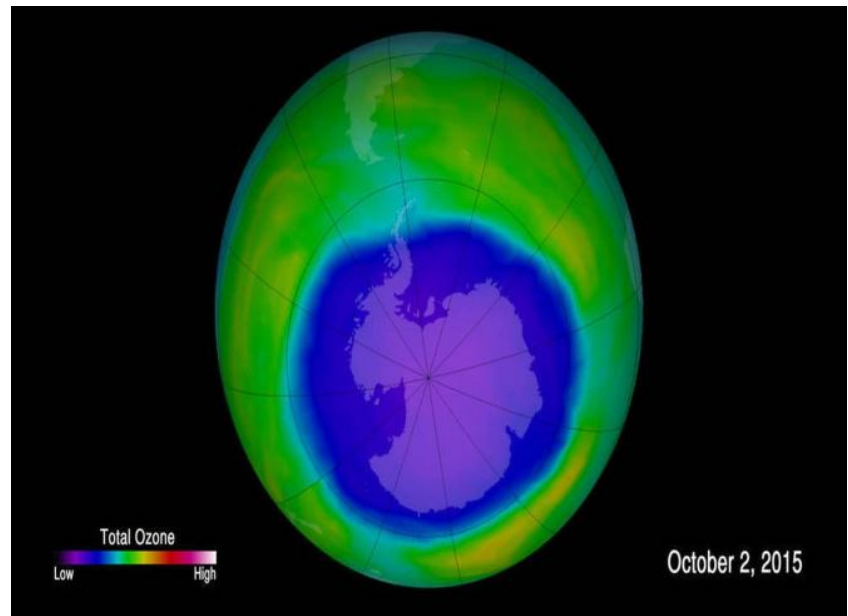

Fig. 3: Total Ozone within the stratosphere. These bluish and purple color in the image displays ozone concentrations above Antarctica taking $2^{\text {nd }}$ Oct. 2015; Photo credit to NASA/Goddard Space Flight Center.

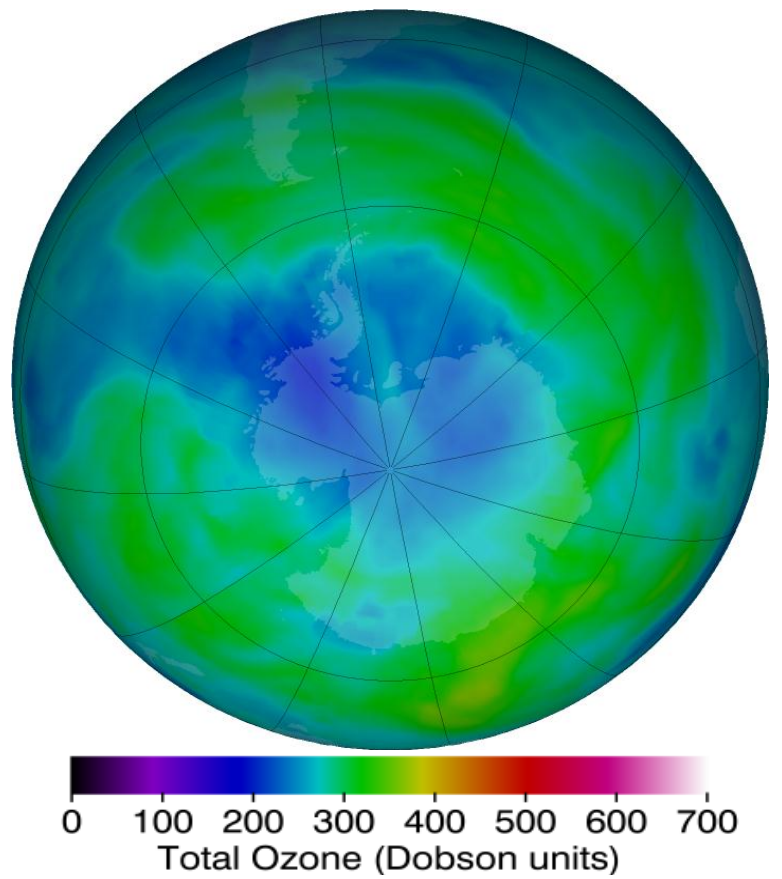

Fig. 4: The 2017 image of Ozone hole. The false-color indicated the total ozone on the Antarctic pole, and the blue and purple colors are the region with the least ozone, while the yellows and reds are the regions with high ozone (credited NASA, 2017). 
Similarly, from direct observation on the region of Antarctica, a column ozone level with less than 220 Dobson Units indicated the loss of the ozone result due to the emitted ODSs mostly compound of hydrobromofluorocarbons and chlorofluorocarbons with high value of chlorine and bromine [24-27].

The analysis of the ozone hole is an evidence that ozone within the lower stratosphere at the amid of $60^{\circ} \mathrm{S}$ and $60^{\circ} \mathrm{N}$ has certainly continuous to decline after the Montreal Protocol (from1998). We also considered that, upper stratospheric ozone is improving; since the hole is decreasing. The recent descending trend in the lower stratosphere prevails, consequential in a descending trend in stratospheric ozone amongst $60^{\circ} \mathrm{S}$ and $60^{\circ} \mathrm{N}$. however, the trend indicated that by 2060 to 2080 , the ozone hole is expecting to have complete heal.

\section{Conclusion}

In order to show the impact of enhanced ozone depleting substances on ozone levels, the study considered all the years for the past few decades during the Southern Hemisphere springtime, chemical reactions usually called ODSs including chlorine and bromine cause ozone in the southern polar province to be destroyed quickly and rigorously. This depleted province is called the "ozone hole". The zone of the ozone hole is determined from the Fig. 3 of the map of total column ozone. It is calculated from the part on the Earth that is surrounded by a line with a standard value of 220 Dobson Units. This value (220 Dobson Units) is chosen because total ozone values that are less than 220 Dobson Units were unable to get it throughout in the historic observations over Antarctica prior Montreal Protocol in the year 1979 [24]. "Similarly, from direct measurements over Antarctica, a column ozone level of less than 220 Dobson Units is a result of the ozone loss from chlorine and bromine compounds" [24, 25].

However, the studies compare the observed data especially those collected after Montreal Protocol months of September 1987. The year-to-year variations are superimposed on a trend encompassing over the last three decades. With the reference period 1994 and 2006, we have also seen the decreasing in ozone hole for all after the Montreal Protocol. Hence, this implies that ODSs are factors responsible for the declined of ozone within the upper stratosphere and be the agent for increased in the ozone hole in the years earlier before it was banned.

The study also explained that, upper stratospheric ozone is improving; the recent descending trend in the lower stratosphere prevails, consequential in a descending trend in stratospheric ozone amongst $60^{\circ} \mathrm{S}$ and $60^{\circ} \mathrm{N}$. These studies have demonstrated that there are possibilities for significant trend indicated that by 2060 to 2080, the ozone hole is expecting to have completed heal. Hence, the details for the continual decrease of ozone in the lower stratosphere are not clear; our models do not prescribe these trends, and thus is a gap for another research.

\section{Acknowledgement}

Ozone hole data for this research were provided by the National Aeronautics and Space Administration (NASA) and National Oceanic and Atmospheric Administration (NOAA). This work has been supported by the co-authors and the East Coast Environmental Research Institute (ESERI) Universiti Sultan Zainal Abidin.

\section{References}

[1] McPeters, R. D., P. K. Bhartia, D. Haffner, G. J. Labow, and L. Flynn (2013), The version 8.6 SBUV ozone data record: An overview, J. Geophys. Res. Atmos., 118, 8032-8039.

[2] Abdullah, N. M., Toriman, M. E., Din, H. M., Aziz, N. A. A., Kamarudin, M. K. A., Rani, N. S. A., Ata, F. M., Saad, M. H., Abdullah, N. W., Idris, M., Jamil, N. R. (2013). Influence of Spatial and Temporal Factors in Determining Rainfall Interception at Dipterocarp Forest Canopy, Lake Chini, Pahang. Malaysian Journal of Analytical Sciences, 17(1), 11-23

[3] Bhartia, P. K., McPeters, R. D., Flynn, L. E., Taylor, S., Kramarova N. A., Frith, S., Fisher, B., and DeLand, M (2013).: Solar Backscatter UV (SBUV) total ozone and profile algorithm, Atmos. Meas. Tech., 6, 2533-2548, doi:10.5194/amt-6-2533-2013, 2013.

[4] Jaafar, O., Toriman, M. E. H., Idris, M. H., Sharifah Mastura, S. A., Juahir, H. H., Aziz, N. A. A., Kamarudin, K. A., Jamil, N. R. (2010). Study of water level-discharge relationship using Artificial Neural Network (ANN) in Sungai Gumum, Tasik Chini Pahang Malaysia. Research Journal of Applied Sciences, 5(1), 20-26.

[5] Kamarudin, M. K. A., Idris, M., \& Toriman, M. E. (2013). Analysis of Leptobarbus hoevenii in control environment at natural lakes. American Journal of Agricultural and Biological Science, 8(2), 142-148.

[6] Kamaruddin, A. F., Toriman, M. E., Juahir, H., Zain, S. M., Rahman, M. N. A., Amri Kamarudin, M. K., Azid, A. (2015). Spatial characterization and identification sources of pollution using multivariate analysis at Terengganu River Basin, Malaysia. Jurnal Teknologi, 77(1): 269-273.

[7] Abdullahi MG, Roslan U, Kamarudin M. K. A., (2016). The Ecological Impacts of Light Pollution at Night-time a Mechanistic Appraisal. International Journal of Environment, Agriculture and Biotechnology, 1(1), 2456-1878.

[8] Abdullahi, M. G., Kamarudin, M. K. A., Umar, R., Endut, A., Khalit, S. I., \& Juahir, H. (2017). Night sky brightness assessment in Nigeria using environmetric and GIS technique. International Journal on Advanced Science, Engineering and Information Technology, 7(1), 28-34.

[9] Toriman, M. E., Gasim, M. B., Yusop, Z., Shahid, I., Mastura, S. A. S., Abdullah, P., Jaafar, M., Aziz, N. A. A., Kamarudin, M. K. A., Jaafar, O., Karim, O., Juahir, H., Jamil, N. R. (2012). Use of $137 \mathrm{Cs}$ activity to investigate sediment movement and transport modeling in river coastal environment. American Journal of Environmental Sciences, 8(4): 417-423.

[10] Gasim, M. B., Toriman, M. E., Idris, M., Lun, P. I., Kamarudin, M. K. A., Nor Azlina, A. A., Mokhtar, M., Mastura, S. A. S. (2013) River flow conditions and dynamic state analysis of Pahang River. American Journal of Applied Sciences, 10(1): 42-57

[11] Frith, S. M., N. A. Kramarova, R. S. Stolarski, R. D. McPeters, P. K. Bhartia, and G. J. Labow (2014), Recent changes in total column ozone based on the SBUV Version 8.6 Merged Ozone Data Set, J. Geophys. Res. Atmos., 119, 9735-9751.

[12] Wahab, N. A., Kamarudin, M. K. A., Gasim, M. B., Umar, R. Ata, F. M., Sulaiman, N. H. (2016). Assessment of total suspended sediment and bed sediment grains in upstream areas of Lata Berangin, Terengganu. International Journal on Advanced Science, Engineering and Information Technology, 6(5): 757-763.

[13] Labow, G. J., R. D. McPeters, P. K. Bhartia, and N. Kramarova (2013), A comparison of 40 years of SBUV measurements of column ozone with data from the Dobson/Brewer network, J. Geophys Res. Atmos., 118, 7370-7378.

[14] DeLand, M. T., Taylor, S. L., Huang, L. K., and Fisher, B. L. (2012): Calibration of the SBUV version 8.6 ozone data product, Atmos. Meas. Tech., 5, 2951-2967.

[15] Kramarova, N. A., Frith, S. M., Bhartia, P. K., McPeters, R. D., Taylor, S. L., Fisher, B. L., Labow, G. J., and DeLand, M. T. (2013): Validation of ozone monthly zonal mean profiles obtained from the version 8.6 Solar Backscatter Ultraviolet algorithm, Atmos. Chem. Phys., 13, 6887-6905.

[16] Newchurch, M. J., Yang, E. S., Cunnold, D. M., Reinsel, G. C., Zawodny, J. M., \& Russell, J. M. (2003). Evidence for slowdown in stratospheric ozone loss: First stage of ozone recovery. Journal of Geophysical Research: Atmospheres, 108(D16).

[17] Steinbrecht, W., H. Claude, and P. Winkler (2004), Enhanced upper stratospheric ozone: Sign of recovery or solar cycle effect? J. Geophys. Res., 109

[18] Tegtmeier, S., M.I. Hegglin, J. Anderson, A. Bourassa, S. Brohede, D. Degenstein, L. Froidevaux, R. Fuller, B. Funke, J. Gille, A. 
Jones, Y. Kasai, K. Krüger, E. Kyrölä, G. Lingenfelser, J. Lumpe, B. Nardi, J. Neu, D. Pendlebury, E. Remsberg, A. Rozanov, L. Smith, M. Toohey, J. Urban, T. von Clarmann, K.A. Walker and H.J. Wang (2013) The SPARC Data Initiative: A comparison of ozone climatologies from international satellite limb sounder. J. Geopyhs. Res.

[19] Hassler, B., Bodeker, G. E., Cionni, I., \& Dameris, M. (2009). A vertically resolved, monthly mean, ozone database from 1979 to 2100 for constraining global climate model simulations. International Journal of Remote Sensing, 30(15-16), 40094018.

[20] Hassler, B., Daniel, J. S., Johnson, B. J., Solomon, S., \& Oltmans, S. J. (2011). An assessment of changing ozone loss rates at South Pole: Twenty-five years of ozonesonde measurements. Journal of Geophysical Research: Atmospheres, 116(D22).

[21] Hassler, B., Petropavlovskikh, I., Staehelin, J., August, T., Bhartia, P. K., Clerbaux, C., ... \& Dufour, G. (2014). Past changes in the vertical distribution of ozone-Part 1: Measurement techniques, uncertainties and availability. Atmospheric Measurement Techniques, 7(5), 1395-1427.

[22] Tummon F., J. Staehelin1, N. Harris2, R. Stolarski3, B. Hassler4, and the SI2N team (2015) Ozone profile changes and the Montrea Protocol. Institute for Atmospheric and Climate Science fiona.tummon@env.ethz.ch ETH Zurich, Universitaetstrasse, 16, Zurich 8092

[23] Abdullahi MG, Toriman ME, Gasim MB, Garba I (2015) Trends Analysis of Groundwater: Using Non-Parametric Methods in Terengganu Malaysia. J Earth Sci Clim Change, 6, 251-262.

[24] Eric R. (2018) National Aeronautics and Space Administration update of Ozone layer from the Southern hemisphere. NASA official website Accessed $4^{\text {th }}$ May 2018.

[25] Paul A. N. (2017) National Aeronautics and Space Administration update of Ozone layer from the northern hemisphere. NASA official website, accessed $5^{\text {th }}$ April 2018.

[26] Azid, A., Juahir, H., Toriman, M. E., Endut, A., Rahman, A., Nordin, M., ... \& Umar, R. (2015). Identification source of variation on regional impact of air quality pattern using chemometric. Aerosol and Air Quality Research, 5, 1545-1558.

[27] Azid, A., Juahir, H., Toriman, M. E., Endut, A., Kamarudin, M. K A., Rahman, A., \& Nordin, M. (2015). Source apportionment of air pollution: A case study in Malaysia. Jurnal Teknologi, 72(1), 83-88. 